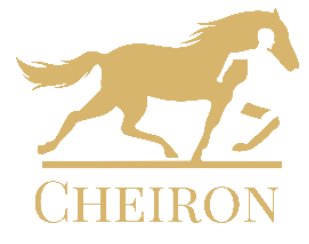

Cheiron: The International Journal of Equine and Equestrian History

Vol. 1, Issue 1/2021

(C) The Authors 2021

Available online at

http://trivent-publishing.eu/

\title{
The Use of Horses in The History by Georgios Akropolites: A Comparison with Historia Romana by Nikephoros Gregoras
}

Alexia-Foteini Stamouli

\begin{abstract}
The short historiographical text by Georgios Akropolites (1217-1282 CE) covers the period of the Latin conquest of the Byzantine Empire. Due to the important position the author held, and his participation in some of the events narrated, his History is a valuable source. This paper concerns the information Akropolites provides about horses, and compares his work with the part of the historiographical text Historia Romana by Nikephoros Gregoras (c. 1292/1295-1358/1361 $\mathrm{CE})$ that describes the same period. Most of the equestrian references consist of details of the kinds of horses used by various people during wars. Akropolites provides more information about the empire of Nicaea, and delivers further interesting details and descriptions concerning horses.
\end{abstract}

\section{Keywords}

Georgios Akropolites; History; horses; wars; Nikephoros Gregoras.

DOI: 10.22618/TP.Cheiron.20211.1.233004

CHEIRON is published by Trivent Publishing

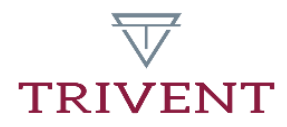

This is an Open Access article distributed in accordance with the Creative Commons Attribution Non Commercial (CC$B Y-N C$-ND 4.0) license, which permits others to copy or share the article, provided original work is properly cited and that this is not done for commercial purposes. Users may not remix, transform, or build upon the material and may not distribute the modified material (bttp:/ / creativecommons.org/licenses/by-nc/4.0/) 


\title{
The Use of Horses in The History by Georgios Akropolites: A Comparison with Historia Romana by Nikephoros Gregoras
}

\author{
Alexia-Foteini Stamouli ${ }^{1}$
}

\begin{abstract}
The short historiographical text by Georgios Akropolites (1217-1282 CE) covers the period of the Latin conquest of the Byzantine Empire. Due to the important position the author held, and his participation in some of the events narrated, his History is a valuable source. This paper concerns the information Akropolites provides about horses, and compares his work with the part of the bistoriographical text Historia Romana by Nikephoros Gregoras (c. 1292/1295-1358/1361 $C E)$ that describes the same period. Most of the equestrian references consist of details of the kinds of horses used by various people during wars. Akropolites provides more information about the empire of Nicaea, and delivers further interesting details and descriptions concerning horses.
\end{abstract}

\section{Keywords}

Georgios Akropolites; History; horses; wars; Nikephoros Gregoras

\section{Introduction}

In order to put the work of these two important chroniclers of Byzantine history into context, it is useful to examine some information about the use of cavalry in the earlier years of Byzantium. There were many factors which influenced Byzantine cavalry operations. The equine and equestrian history of Byzantium is interwoven with that of other nations of the medieval period. Byzantium was heir to the Roman improvement policies regarding breeding horses for different uses. It also inherited improved cavalry warfare. The agrarian economy of the empire produced both the horses and the fodder that maintained them. The importance of horses is reflected in the many laws which include equestrian elements and various texts relating to their use. Veterinary medicine was given prominence as an activity.

By the beginning of the medieval period, infantry was no longer the most important arm of the military. Cappadocia, Phrygia and particularly Syria were regions where horse-breeding had been developed to a high degree. ${ }^{2}$ The best source for Justinian's wars is Procopius of Caesarea. ${ }^{3}$ From his eight books, we know how important cavalry was to the Byzantine army. The methods of mounting the units and shipping the animals are outlined, and details of

\footnotetext{
${ }^{1}$ Department of Museum Studies, University of Patras, Greece.

2 Ann Hyland, The Medieval Warborse from Byzantium to the Crusades (Pennsylvania: Combined Publishing, 1996), 18.

${ }^{3}$ Hyland, The Medieval Warborse, 19.
} 
cavalry maintenance and subsequent deployment and usage are set down. ${ }^{4}$ The Strategikon of the Emperor Maurice details how the horse was equipped, cared for, allocated rations, and used on the march, in formation, and in the hunt. ${ }^{5}$ When in the tenth century Leo VI wrote Tactica it was broadly based on his predecessor, although some of the enemies of Byzantium had been replaced by new opponents. ${ }^{6}$ From the seventh century, there was a reduction in foreign mercenaries and an increase in home recruitment. The Byzantine Empire was organized into administrative and military districts known as themes, some of which reflect particular cavalry traditions. For example, the Armenians had a long history of armored cavalry. ${ }^{7}$ Any family owning land owed military service, and the soldier was obliged to present himself fully equipped and mounted. The De Administrando Imperio of Constantine Porphyrogenitus, a work written towards the middle of the tenth century gives information about horses levied from the provinces of the Peloponnese in the time of Romanus I Lekapenus. Constantine Porphyrogenitus' Book of Ceremonies gives valuable information on the army's back-up services. ${ }^{8}$ With this background in place, we can now turn to our writers.

Georgios Akropolites (1217-1282 CE) was born and died in Constantinople. ${ }^{9}$ He came from a family of civil functionaries. ${ }^{10} \mathrm{He}$ completed his grammar schooling in Constantinople and began his higher education at the court of John III Vatatzes at the age of $17 .{ }^{11}$ Akropolites studied philosophy with Nikephoros Blemmydes until 1246, when he accompanied Emperor John on a three-month campaign ${ }^{12}$ in Serres and Thessaloniki. ${ }^{13}$ Akropolites accomplished ambassadorial missions. ${ }^{14} \mathrm{He}$ taught Theodore II logic and philosophy ${ }^{15}$ and continued to be

\footnotetext{
4 Ibidem, 21.

5 Ibidem, 26.

${ }^{6}$ Ibidem, 34.

7 Ibidem, 36.
}

8 Ibidem, 37. On the Byzantine cavalry, see also: Timothy Dawson, Byzantine Cavalryman: c.900-1204 (Osprey Publishing, 2009); George Dennis, "The Byzantines in Battle," in Byzantium at War (9th-12th c.), ed. Kostas Tsiknakis (Athens: National Hellenic Research Foundation - Centre for Byzantine Research, 1997), 165-178; John Haldon, Warfare, State and Society in the Byzantine World, 565-1204 (London: UCL Press, 1999); Taxiarchis Kollias, Byzantinische Waffen: ein Beitrag zur byzantinischen Waffenkunde von den Anfangen bis zur lateinischen Eroberung (Vienna: Verlag der Osterreichischen Akademie der Wissenschaften, 1988); Stavros Lazaris, Le cheval, animal de guerre et de loisir dans l'Antiquité et au Moyen Áge: Actes des Journées d'étude internationales organisées par l'UMR 7044 (Études des civilisations de l'Antiquité), Strasbourg, 6-7 novembre 2009 (Turnhout: Brepols, 2012); Stavros Lazaris, "Le cheval de guerre dans le haut Moyen Âge: élevage, thérapeutique et équipements hippiques," in Vie et mort du cheval: des pratiques médiévales aux traditions camarguaises. Actes du Xe congrès de la Société d'archéologie médiévale (Arles, 3-5 mai, 2012), 23-44, ed. Élizabeth Lorans (Caen: Arles, 2017); Stavros Lazaris, "Rôle et place du cheval dans l'Antiquité tardive: Questions d'ordre économique et militaire," in Animal and Environment in Byzantium (7th-12th c.), ed. Ilias Anagnostakis, Taxiarchis Kolias, Eftychia Papadopoulou [National Hellenic Research Foundation Institute for Byzantine Research. International Symposium 21] (Athens: The National Hellenic Research Foundation, 2011), 245-272; Eric McGeer, Sowing the Dragon's Teeth: Byzantine Warfare in the Tenth Century (Washington, D.C.: Dumbarton Oaks Studies 33, 1995); Eric McGeer, "Infantry versus Cavalry: The Byzantine Response," Revue des études byzantines 46 (1988): 135-145; Warren Treadgold, Byzantium and Its Army, 284-1081 (Stanford: Stanford University Press, 1998).

${ }_{9}^{9}$ Ruth Makrides (ed.), George Akropolites The History (Oxford: Oxford University Press 2007), 6.

${ }_{10}$ Makrides, George Akropolites The History, 7.

11 Ibidem, 7-8.

12 Ibidem, 9.

13 Ibidem, 10.

14 Ibidem, 11.

15 Ibidem, 9. 
responsible for drafting documents under Theodore II. ${ }^{16}$ In 1256 Akropolites also undertook military duties. Upon his return to Constantinople, he began to teach ${ }^{17}$ philosophy and rhetoric. ${ }^{18}$ John Pediasimos and Gregory of Cyprus were two of his students. ${ }^{19}$

The short historiographical work by Georgios Akropolites covers the period of Latin rule (1204-1262). ${ }^{20}$ Due to the important position of the author and his participation in the events that he narrates, his history is a valuable primary source.

Nikephoros Gregoras (c. 1292/1295-1358/1361 CE) was born in Heraklea Pontica, in Paphlagonia (modern-day Karadeniz Ereğlisi). At the age of twenty he was sent to study in Constantinople, and he surpassed every other scholar of his time due to the variety of his knowledge and interests. He had a remarkable education and interest in the classics, and was an expert in astronomy. His interests also included mathematics, philosophy and music. $\mathrm{He}$ greatly influenced the intellectual and political development of his time and left a rich heritage. He also dedicated his life to teaching. From 1340 he abandoned his literary and scientific activity to devote himself entirely to the composition of his History and especially of his theological treatises. ${ }^{21}$ The extensive historiographical text by Nikephoros Gregoras, consisting of 37 books and entitled Historia Romana, covers the years from 1204 to $1359 .{ }^{22} \mathrm{It}$ is his most important work and provides abundant references to horses as part of the daily life in the society it describes. ${ }^{23}$

The next section compares the information about horses provided by Georgios Akropolites and by Nikephoros Gregoras in his historiographical work about the same period ${ }^{24}$ in cases where the two authors refer to the same event or provide similar information.

\footnotetext{
16 Ibidem, 11.

17 Ibidem, 12.

18 Ibidem, 14.

${ }^{19}$ Ibidem, 13.
}

20 August Heisenberg (ed.), Georgii Acropolitae opera, v. i-ii. (Leipzig: Teubner, 1903, reprint Stuttgart, 1978.) The text has been digitalized by the University of the Aegean (http://khazarzar.skeptik.net/pgm/PG_Migne/Georgius\%20Acropolita_PG\%20140/Annales.pdf). Further references to this source will be given parenthetically throughout the paper.

${ }^{21}$ Martin Hinterberger, "Les Vies des saints du XIVe siècle en tant que biographie historique: l'oeuvre de Nicéphore Grégoras," in Les Vies des Saints à Byzance: Genre littéraire ou biographie historique?, Actes du $2^{e}$ colloque international philologique, Paris, 6-7-8 juin 2002, ed. Paolo Odorico, Panagiotis Agapitos [Dossiers byzantins - 4], (Paris 2004), 281-301; Vitalien Laurent, "La vie de Jean, métropolite d'Héracleé du Pont," Archeion Pontou 6 (1935): 29-63; Sophia Mergiali, L'enseignement et les lettrés pendant l'époque des Paléologues (Athens: Etaireia ton filon tou laou, 1996); Iliana Paraskevopoulou, Ta Agiologika Erga tou Nikiforou Grigora [The Hagiographical Works by Nikephoros Gregoras] (Doctoral thesis), (Thessaloniki, 2008); Steven Runciman, The Last Byzantine Renaissance (Cambridge: Cambridge University Press, 1970).

${ }^{22}$ Ludovicus Schopen - Immanuel Bekker (eds.), Nicephori Gregorae Historiae Byzantinae (Bonn: Corpus Scriptorum Historiae Byzantinae 25-27, 1829-1855). The text has been digitalized by the University of the Aegean (http://khazarzar.skeptik.net/pgm/PG_Migne/Nicephorus\%20Gregoras_PG\%20148149/Historia\%20Romana.pdf). Further references to this source will be included parenthetically in the text.

23 About the late Byzantine period see: Cyril Mango, The Oxford History of Byzantium (Oxford: Oxford University Press, 2002); Donald Nicol, The last centuries of Byzantium (Cambridge: Cambridge University Press, 1993); George Ostrogorsky, History of the Byzantine State (New Brunswick: Rutgers University Press, 1969).

${ }^{24}$ I discuss Nikephoros Gregoras's work in Alexia-Foteini Stamouli, "Roman and enemy horses and riders: the testimony of Historia Romana by Nikephoros Gregoras," Virtual International Medieval Congress 2020, University of Leeds, 8 July 2020, Session: Horses across Borders I, forthcoming. 


\section{The cavalry in battles}

The contribution of the cavalry is important in several campaigns and battles. During his first campaign against the Bulgarians (December 1254-December 1255), due to the decision of the majority to cross the Hellespont and stop the Bulgarians and his own willingness and zeal,

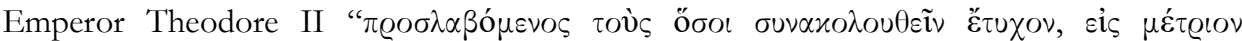

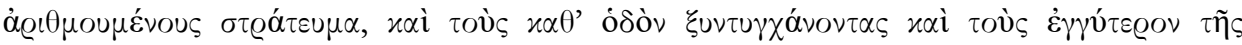

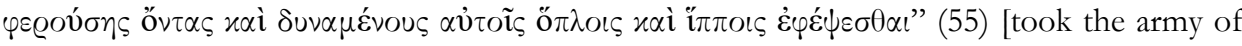
moderate size that happened to follow him and the people he met along the way as well as those who were near the road and able to follow with their own weapons and horses]; he crossed the Hellespont and reached Adrianople. ${ }^{25}$ When Theodore was informed where the

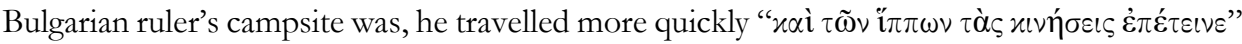
(56) [and increased the horses' speed]. Those who were in advance of the Roman army fell into the hands of the Bulgarians, were killed, captured or fled to the Bulgarians, revealing that

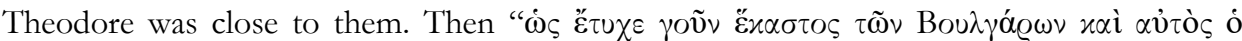

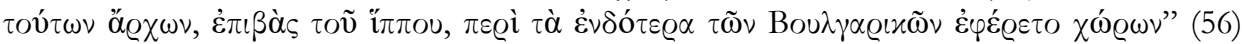
[the Bulgarians - even their leader - mounted their horses as it happened and made for the interior of the Bulgarian lands]. Their faces - even that of the ruler - were torn by the dense

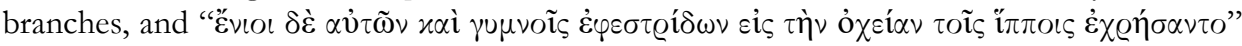
(56) [Some of them rode bareback]. The next day, Theodore, finding the place without a Bulgarian army, occupied Beroe in Thrace (today's Stara Zagora, in Bulgaria). Apparently, this

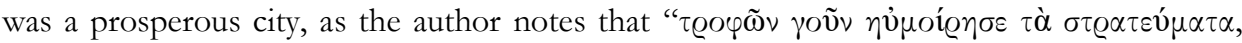

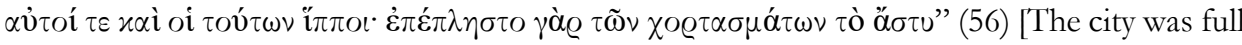
of food for both the troops and the horses]. ${ }^{26}$

The text contains information about the sort of horses used by various peoples during wars. John (Ioannitzes) was emperor of the Bulgarians during the conquest of Constantinople. The inhabitants of Adrianople asked for his help against the Latins and he hurried with the Scyths $^{27}$ (the Cumans). ${ }^{28}$ On this occasion, the author informs about the different ways in

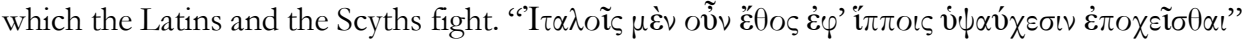
(13) [It is the custom of the Italians to ride on towering horses] and have their whole body covered with weapons. They, therefore, find it hard to attack their enemies quickly. The Scyths are more lightly armed and assault their enemies more freely. Since the Italians were not aware of this, ${ }^{29}$ they were defeated at the Battle of Adrianople (1205). Gregoras refers to the suitability of the land of Orestiada for horses and to the booty the Bulgarians and Scyths took, which included Latin horses.

During the war with Epirus (1256-1257), the army of Manuel Lapardas sent by Emperor

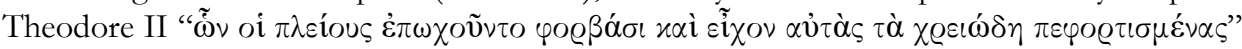
(71) [rode mostly mares loaded with the essentials]. In Vodena they encountered the army sent against the Romans by the renegade Michael II, the despot, with his illegitimate son

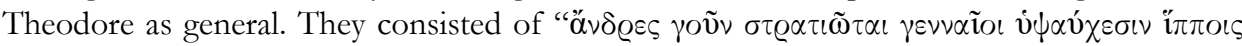

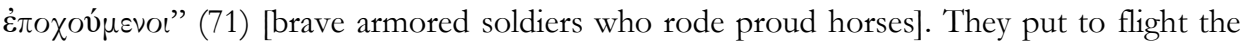

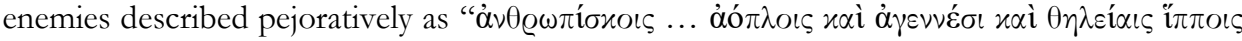

\footnotetext{
25 Makrides, George Akropolites The History, 283.

26 Ibidem, 285.

27 Ibidem, 139

28 Ibidem, 142.

${ }^{29}$ Ibidem, 139.
} 


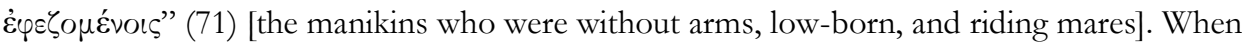
Michael Komnenos was informed of the events he rushed against the enemies. He hit the

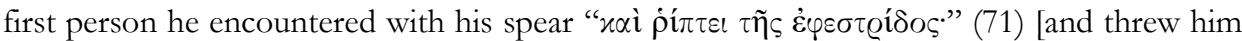
from the saddle]. ${ }^{30}$ It was the illegitimate son of the renegade Michael, Theodore.

The following information is given about the battle of Pelagonia (1259). In January 1259,

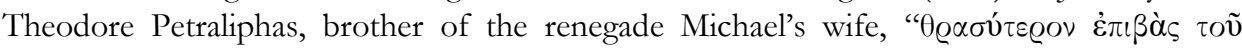

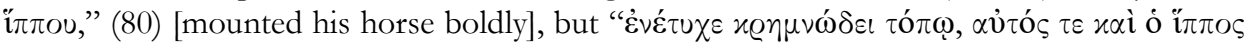

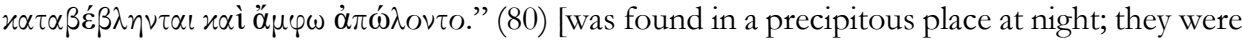
both cast down and perished]. Those around the renegade had encamped in the parts of Kastoria, and the Roman forces that were moving against him were led by the brother of Emperor Michael Komnenos, the sebastokrator John. ${ }^{31}$ The renegade Michael received the support of a considerable military force ${ }^{32}$ from his son-in-law, the king of Sicily Manfred: ${ }^{33}$

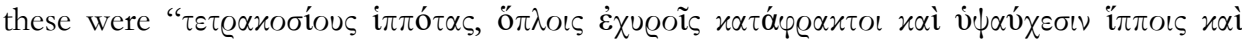

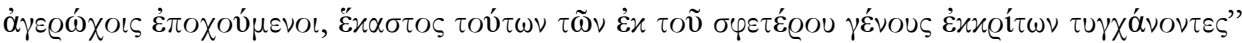
(81) [four hundred eminent armed knights, mounted on powering and arrogant horses]. The forces of the emperor's brother, the sebastokrator John, allowed the forces of the renegade

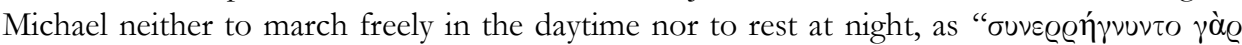

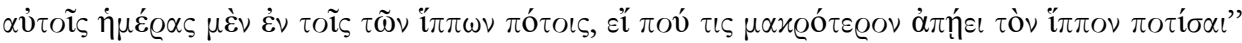
(81) [They clashed with them in the day, when they were watering their horses, if someone would distance himself to water his horse]. ${ }^{34}$ The renegade Michael finally fled one night with

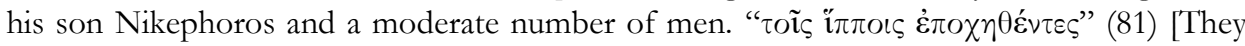
mounted their horses], as they knew the roads well. In the morning, his escape became known to the army, who also turned to flight. The allied army sent to the renegade by Manfred, " $\mathfrak{\varsigma} \varsigma$

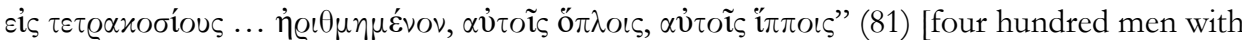
their arms and their horses] were taken by four men (among whom were the megas domestikos Alexios Strategopoulos and Nikephoros Rimpsas) who were sent as captives to the emperor. ${ }^{35}$

\section{Horses as belongings}

Horses also constitute an important booty or acquisition in other instances, as at the Battle of Adrianople (1205) mentioned above, as well as being exchanged as gifts. In the spring of 1255, Theodoros II from Tzepaina (in north-west Rodopi) invited Alexios Strategopoulos and Constantine Tornikes from Serres, who, however, proved bad generals. Although they encountered neither enemy armies nor men capable of fighting them, but only heard the clashing of weapons, various noises and sounds of trumpets, they fled in a disorderly fashion,

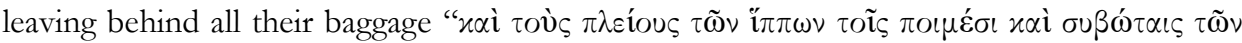

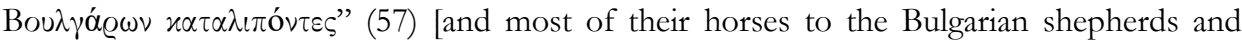

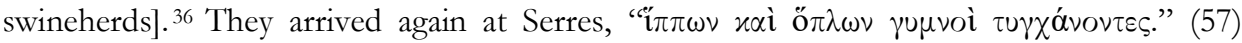
[stripped of horses and arms].

\footnotetext{
${ }^{30}$ Ibidem, 330.

31 Ibidem, 356.

32 Ibidem, 360.

33 Ibidem, 362.

34 Ibidem, 360.

35 Ibidem, 361.

36 Ibidem, 287.
} 
It is also worth mentioning that the ruler of the Bulgarians asked his father-in-law, the Russian Ouros (Rostislav Michailovic'), to mediate matters concerning peace with the Romans $^{37}$ (the agreement was probably signed on June 29, 1256). Horses were among the 20,000 gifts ${ }^{38}$ that Ouros received before leaving the region of Regina. ${ }^{39}$ Further, as will be mentioned later, during his flight to the Turcomans ${ }^{40}$ in 1256, Michael Komnenos Palaiologos was deprived of all his horses.

\section{Transport}

Triremes were used to transport cavalry, as attested by the reference to the conquest of Rhodes by the Genoese and its surrender to the Romans (1248-1250). The epi tou kerasmatos John Komnenos Kantakouzenos, dispatched by imperial order, ${ }^{41}$ was besieging the city of Rhodes. In May 1249

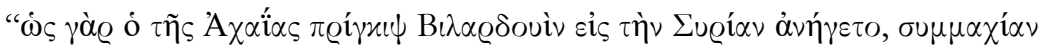

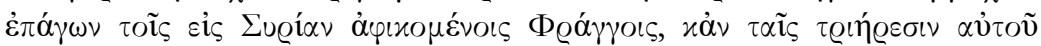

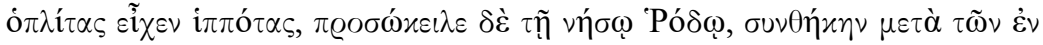

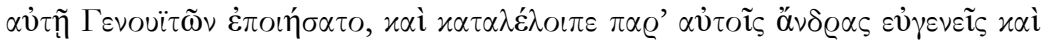

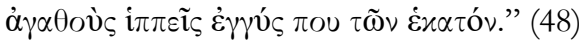

[the prince of Achaia, William II of Villehardouin, ${ }^{42}$ sailing to Syria bringing allies to the Franks there, having on his triremes (400 armed) cavalrymen, ran ashore on the island of Rhodes, made an agreement with the Genoese and left to them approximately a hundred noble and worthy cavalrymen.]

They plundered the entire countryside. ${ }^{43}$ The emperor of Nicaea, John III (Doukas

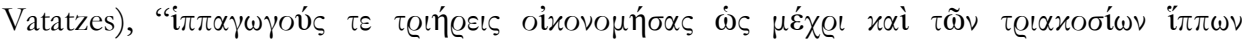
$\dot{\varepsilon} \pi \iota \varphi \dot{\varepsilon} \varrho \varepsilon \sigma \theta \alpha \iota "$ (48) [arranged for horse-carrying triremes to transport up to three hundred horses] with Theodore Kontostephanos as their general and commander of the battle according to the orders John III had issued. Kontostephanos arrived at the island of Rhodes with the triremes and routed the Latins. All the Latins who were plundering the island were slaughtered as commanded by John Kantakouzenos. The Frankish cavalry was destroyed by superior imperial military capability, and the Genoese were forced to surrender the town to the Romans. ${ }^{44}$

Further details include the fact that mules and camels were used to transport the essentials to a military camp during the winter of 1252-1253. Emperor John III (Doukas Vatatzes) had pitched tent near the lake of Ostrovos. ${ }^{45}$ His generals plundered ${ }^{46}$ the territories ${ }^{47}$ of Despot Michael II. John's army was dissatisfied at the fact they had to stay and have achieved almost

\footnotetext{
37 Ibidem, 303.

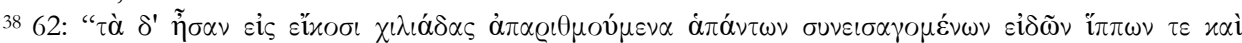

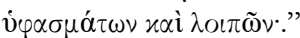

39 Ibidem, 304.

40 Ibidem, 315.

41 Ibidem, 246.

42 Ibidem, 247.

43 Ibidem, 246.

44 Ibidem, 247.

45 Ibidem, 249.

46 Ibidem, 250.

47 Ibidem, 249.
} 


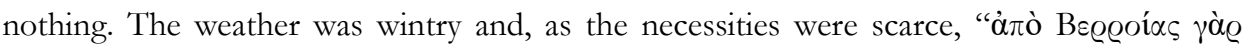

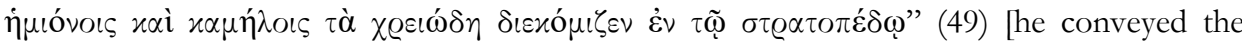
necessities into the camp from Berroia on mules and camels]. ${ }^{48}$

Of course, horses were also used for transport, as by Theodore II in 1255, a case which will be mentioned later. Horses were ridden not only into battle but while the army was on the move. It has already been reported that the Bulgarians fled on horseback, even without saddles, presumably because they were taken by surprise, during Theodore II's first campaign against them.

On September 26 or 27, ${ }^{49}$ 1246, the emperor of Nicaea, John III Doukas Vatatzes, crossed the Hebros River. Due to the season, the river " $\pi$ ooì $\gamma \grave{\alpha} \varrho$ ï $\pi \pi \omega \nu$ vं $\pi \tilde{\eta} \varrho \chi \varepsilon \beta \alpha \tau o ́ \varsigma$ " (43) [was fordable for the horses], ${ }^{50}$ the dry season in this region being from June to October. ${ }^{51}$ When John reached the middle of the river, he received a message about the death of the ruler of the Bulgarians, Asan's son, Kaliman. ${ }^{2}$

The situation is of course made difficult for those who are forced to fight on foot instead of using the cavalry. During the conquest of Tzouroulos (in eastern Thrace) by the emperor John III Duke Vatatzes in the summer of 1247, his sister-in-law, Eudokia, wife of Ansel of

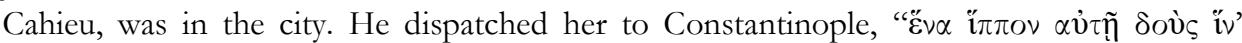

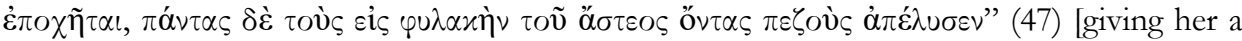
single horse for her mount, while all those who were guarding the town were infantry]. ${ }^{53} \mathrm{~A}$ similar example is mentioned during the second campaign of Theodore II against the Bulgarians.

An important condition for the appropriate use of the cavalry is of course the existence of suitable terrain. Referring to the movement of the army in the autumn and winter of 1255 , Akropolites informs us that Emperor Theodore II and the entire army were aiming to reach Tzepaina, which is at an altitude of 300-600 meters. In the town of Vatkounion he was informed that their way there would be easy. Because of the difficulties they encountered, however, the next day it was decided to descend to the plain. ${ }^{54}$ The emperor remained as a

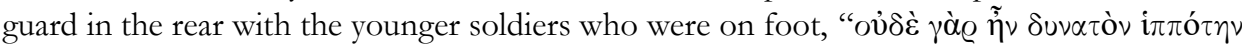

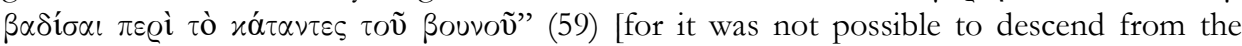
mountain on horseback]. ${ }^{55}$

\section{Attacks on horses and accidents}

Attacks on horses in order to incapacitate them as well as their riders are described in the writings of both Akropolites and Gregoras, as, for instance, during the battle of Antioch-onthe-Maeander (1211). ${ }^{56}$ Alexios III Angelos was received by the sultan of Iconium, Iathanites. ${ }^{57}$ An embassy was sent to Alexios's son-in-law, Theodore Laskaris in Nicaea. The sultan was besieging Antioch. When he got near the city, Theodore sent the ambassador to inform his

\footnotetext{
48 Ibidem, 250.

49 Ibidem, 228.

50 Ibidem, 225.

51 Ibidem, 228.

52 Ibidem, 225.

53 Ibidem, 245.

54 Ibidem, 293.

55 Ibidem, 294.

56 Ibidem, 130.

57 Ibidem, 124.
} 
lord. The information provided by Gregoras indicating that two thousands of Thedore's men were horsemen and that the place where the battle unfurled was unsuitable for cavalry is omitted by Akropolites. The sultan struck Theodore on the head with a mace, dizzying him

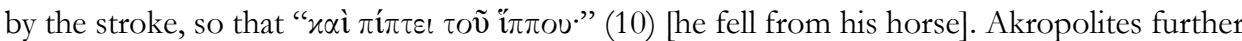
clarifies that the horse also lost its footing because of the stroke; it may have received a second

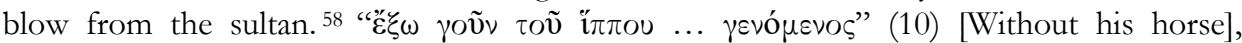
Theodore seemed to be strengthened by a divine force. With his sword, he struck the feet of the sultan's horse. In contrast to Gregoras, according to whom Theodore cut the horse's front legs, Akropolites states that Theodore struck the horse's hind legs when the sultan turned and ordered to take him away, further clarifying that the sultan was on a mare of enormous size. ${ }^{59}$ As a result, the sultan was thrown down as if from a tower and was immediately decapitated, no one understood by whom. ${ }^{60}$

During his second campaign against the Bulgarians (in the spring-summer of 1256), Theodore II gathered his army to cross the Hellespont. The forces that were in Didymoteichon, however, moved against the Scyths. As was their custom, the Romans were clad in burdensome armor, while the Scyths were lightly armed warriors and used bows:

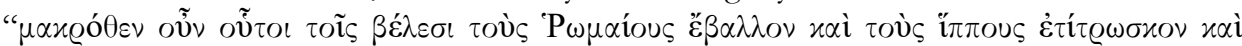

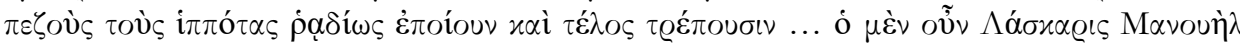

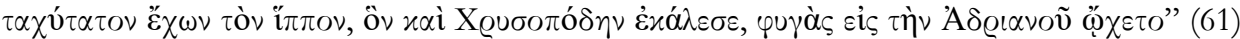
[They struck the Romans with arrows from a distance and wounded their horses and easily turned the horsemen into foot-soldiers and finally put them to flight ... The general Manuel Laskaris had a swifter horse, which he called Goldenfoot and was able to take refuge in Adrianople]. ${ }^{61}$ This is the only testimony of the name of a horse in the History by Akropolites, while no such example is mentioned by Gregoras. The act of naming clearly indicates a special relationship between this horse and its owner.

Deaths of people through the action of horses are also mentioned. In 1255 the leader of the Melenikon (located in Bulgaria) army, Dragotas, revolted and besieged Melenikon. Theodoros II reached Serres as quickly as he could with an army accustomed to fight in close

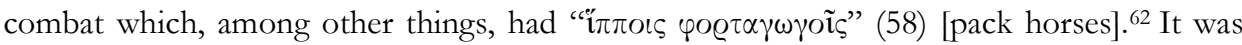
reported that the rough terrain of Rupeli (Rupel, in Sidirokastro), where the river Strymon

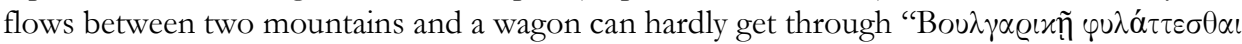

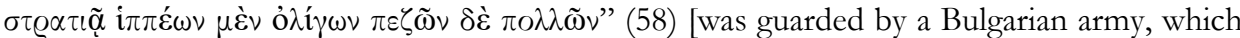
had few horsemen and many foot-soldiers]. The Bulgarians had also constructed gates there.

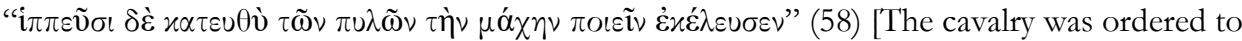
join battle in front of the gates], while the infantry fought from above, from the mountain. The Bulgarians turned to flight. After the information the Bulgarians received from those of

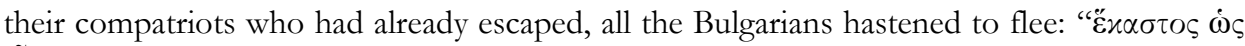

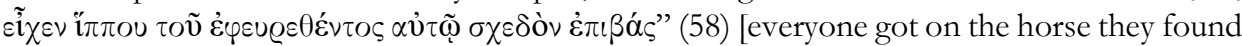
nearby as best they could]. There was no moon; the terrain was irregular, and it was difficult

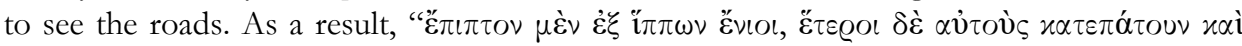

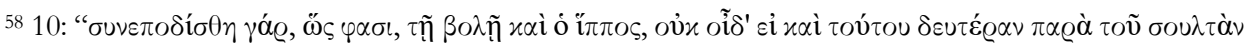
$\lambda \alpha \beta$ ßóvos $\pi \lambda \eta \gamma \eta \dot{\nu} v . "$

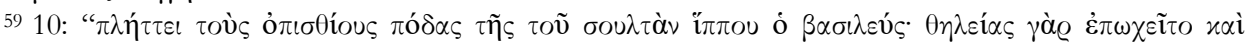

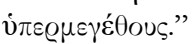

${ }^{60}$ Makrides George Akropolites The History, 131.

${ }^{61}$ Ibidem, 301

${ }^{62}$ Ibidem, 288.
} 


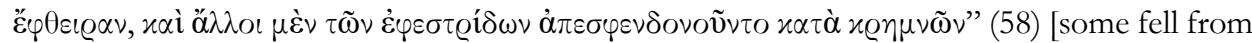
their horses, others were trampled and killed. Others were hurled from their saddles, as from

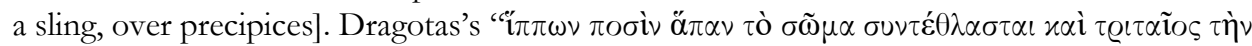

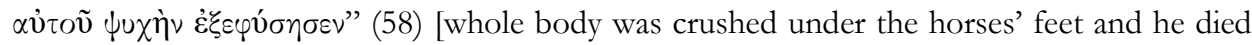
three days later]. ${ }^{63}$

\section{Care for horses}

Care is taken to feed the army horses and to find water, as regular provision of water is essential to their well-being. One example of the necessity to ensure food and water for both horses and men has been mentioned above in the description of the occupation of Beroe by Theodore II, with the chronicler specifying that the city had plenty of food for the horses. The chronicle includes other examples of preoccupation with the horses' welfare. Thus, for the battle of Vodena (Edessa), which took place in 1257, the forces of Michael Komnenos

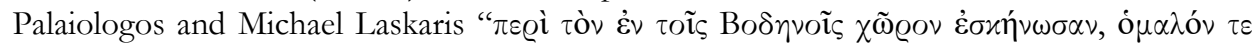

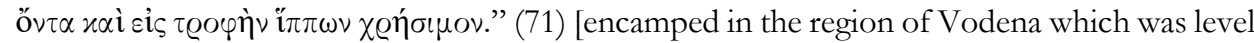
and useful for the feeding of horses]. ${ }^{64}$

Another such example is mentioned in 1261, when after the Resurrection in the spring of this year, the emperor went to a place called Klyzomene. The emperors were accustomed to pass most of the spring season there, upon leaving Nymphaion. One of the reasons

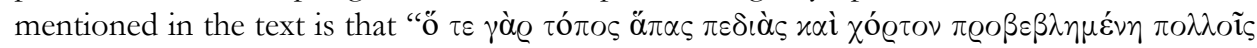

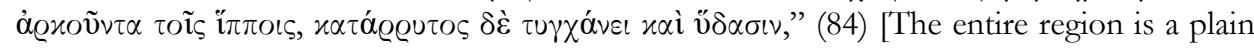
and provides sufficient pasturage for many horses; it is also irrigated]. ${ }^{65}$

During the movement of the army in the autumn and winter of 1255, Emperor Theodore II with his entire army made the journey ${ }^{66}$ through Neustapolis. The place is without water or habitation, and passage for a large number of troops is difficult: the author highlights the

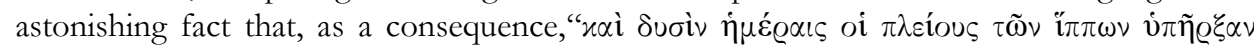

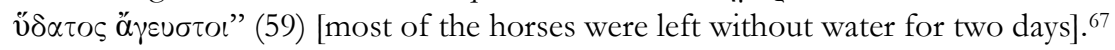

\section{Getting down from the horse}

Descending from a horse, or dismounting, is considered as a sign of submission or respect. The inhabitants of Adrianople sent an embassy to the emperor of Nicaea, John III Duke Vatatzes, asking to dispatch an army to them and free them from the Latins. ${ }^{68}$ The protostrator Ises and John Kammytzes crossed the Hellespont, travelled through Macedonia and arrived at Adrianople. When the ruler of Epirus, Theodoros Komnenos, arrived there, he persuaded the inhabitants to let him enter the town. The army of Ises and Kammytzes would leave on

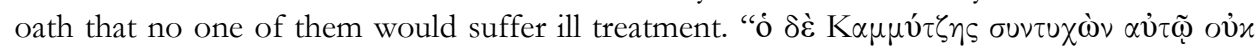

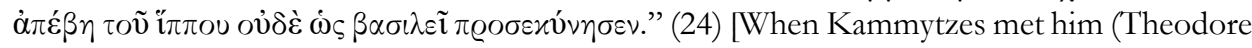
Komnenos), he did not dismount or make obeisance as to an emperor.] Theodore Komnenos was indignant at this. ${ }^{69}$ These events took place at the end of 1224 and the beginning of 1225.

\footnotetext{
63 Ibidem, 289.

64 Ibidem, 330.

65 Ibidem, 370.

66 Ibidem, 291.

${ }^{67}$ Ibidem, 292.

68 Ibidem, 171.

69 Ibidem, 172.
} 
Akropolites refers to descending from horseback in his account of the transference of power in Thessaloniki in 1246 from Despot Demetrios, son of Theodore Komnenos Doukas, to Emperor John III Doukas Vatatzes. Demetrios's sister, Eirene, wife of Asan II of the Bulgarians, fell on her knees and implored that her brother not suffer the loss of his eyes. ${ }^{70}$

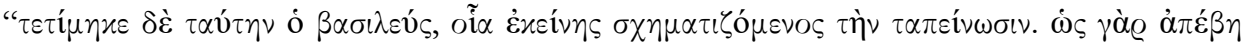

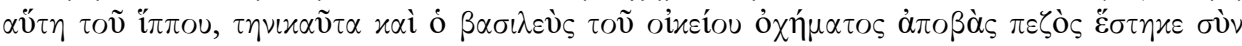
$\alpha \dot{v} \tau \tilde{\eta} . "$ (45) [The emperor (John) honored her by assuming a posture of humility like hers. When she dismounted from her horse, he descended from his own carriage and stood on foot with her]. ${ }^{71}$

\section{Offices related to horses}

We are also informed that the trappings of the horse were decorated to reflect the position of its rider. Thus, Pelagius, the bishop (legate) whom pope Innocent III dispatched to Constantinople, in 1213, bore all the privileges of the pope. Among other things,

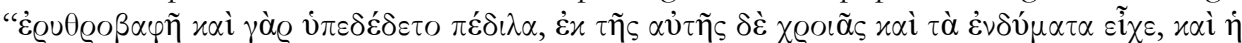

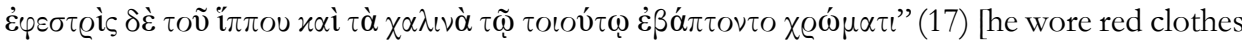
and shoes, the same color as his horse's saddle and reins]. ${ }^{72}$ Akropolites provides information about an ecclesiastical office, while Gregoras mentions the red saddles of the imperial horses and the yellow jewels of panypersevastos's horse.

The office of megas konostablos is mentioned four times. The title originally meant the officer who was responsible for the supervision of the stables of the imperial court. At that time, the office was held by Michael Komnenos Palaiologos ${ }^{73}$ who initially fled to the land of the Muslims. ${ }^{74}$ The author discussed this flight with the emperor in Thessaloniki in September 1256. Michael himself in his letters to those who were in command of armies in Bithynia and Mesothynia ${ }^{75}$ attributed his flight to his fear of the emperor. Michael Komnenos arrived at the dwellings of the Turcomans, a people on the boundaries of the Persians who hated the Romans. They snatched all his possessions, ${ }^{76}$ including his horses. ${ }^{77}$ Gregoras also informs the reader that after his return to the Romans Michael Komnenos Palaiologos was honored with the office of megas konostablos, as before. Michael Glabas is later on mentioned by Gregoras as holding this position.

\section{Trials by battle, transportation of brides, and other uses of horses}

A judicial duel of horsemen in order to reveal betrayal is also witnessed and reported by Akropolites. Indeed, the trial by combat was used by Emperor John III (Doukas Vatatzes). Two inhabitants of Melenikon reported their conversation about Michael Komnenos

\footnotetext{
${ }^{70}$ Ibidem, 237.

71 Ibidem, 238

72 Ibidem, 154

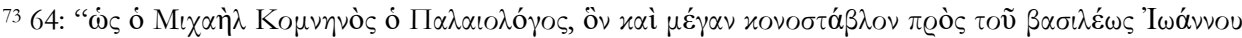

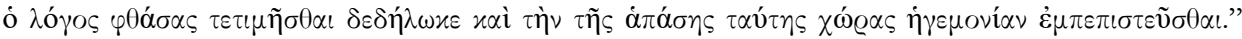
Michael Palaiologos had been given the office of megas konostablos in the winter of 1253-1254 (Makrides George Akropolites The History, 314).

${ }^{74}$ Makrides George Akropolites The History, 312.

75 Ibidem, 313.

76 Ibidem, 315.

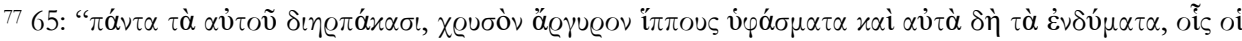

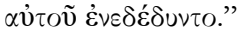


Palaiologos, son of the megas domestikos, ${ }^{78}$ to Nicholas Manglavites, ${ }^{79}$ who reported this conversation to the emperor (in 1252). ${ }^{80}$ The trial took place later, when the emperor was in Philippi. The accused claimed that their conversation did not take place with the knowledge

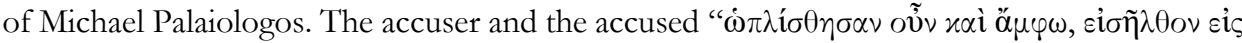

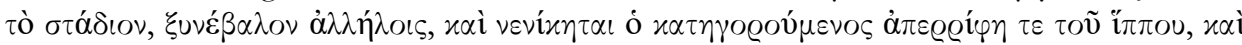

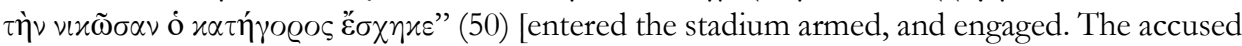
was defeated and thrown from his horse] without, however, being mortally wounded]. ${ }^{81}$ Akropolites was an eyewitness and a judge. Judicial combat or duel was applied in the west in cases of treason, among other instances, when other means of discovering the truth were not available. Although this practice was not a procedure of Roman law, it was an accepted custom. ${ }^{82}$

A further unusual detail relating to horses is of note. In 1237, when the Bulgarian Asan took back his daughter Helen, ${ }^{83}$ who had married Theodore II Laskaris, she was crying and bewailing the separation from her mother-in-law, the empress Eirene, and her husband. The following description confirms the Bulgarian's cruelty, as the author states that "ö $\tau \varepsilon \ldots$. $\tau$ ò $v$

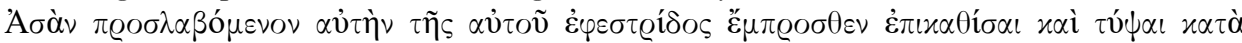

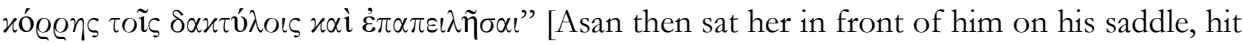
her and threatened her]. ${ }^{84}$

In 1246, Dragotas, a Bulgarian, ${ }^{85}$ lived in Melenikon and was the military commander at Serres ${ }^{86}$ when the emperor of Nicaea, John III Doukas Vatatzes, conquered Serres. After the death of his master ${ }^{87}$ Dragotas sent an embassy to John and persuaded the inhabitants of Melenikon to become the emperor's subjects. Over five hundred men went to the place called Valavisda ${ }^{88}$ (modern Sidirokastro, northwest of Serres) to meet John III. The author

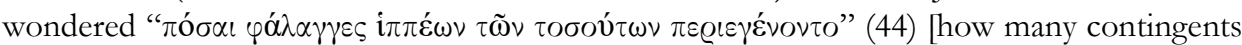
of cavalrymen overcame men such as these], meaning that everything is possible only through God's grace.

Emperor John III suffered from apoplexy. In Nymphaion, while he was in the palace he

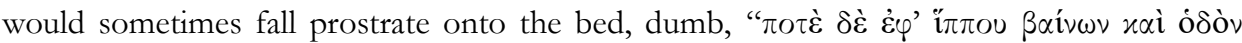

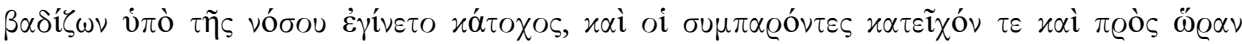

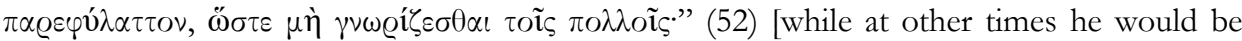
seized by the illness as he rode horseback and proceeded along the road, and those who were with him would hold him and protect him for a time so that it would not become known to the people]. Upon recovering consciousness, he would return to the palace slowly. Sometimes he would be carried in the palace by his retainers, enthroned on a litter. ${ }^{89}$ The events concern

\footnotetext{
78 Makrides George Akropolites The History, 260.

${ }^{79}$ Ibidem, 259.

80 The trial by battle took place in order to prove if the conversation between two inhabitants of Melenikon concerning Michael Komnenos was known to him (Michael), if one of the inhabitants (the accused) had informed Michael about this conversation, as claimed by the accuser.

81 Makrides George Akropolites The History, 260.

82 Ibidem, 265.

83 Ibidem, 197.

84 Ibidem, 198.

85 Ibidem, 226.

86 Ibidem, 229.

87 Ibidem, 226.

88 Ibidem, 231.

89 Ibidem, 270.
} 
the period from the end of 1253 to the end of 1254 . According to Gregoras, John Doukas, who suffered from frenzy or epilepsy, often risked falling off his horse.

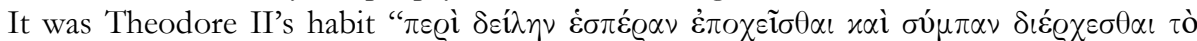

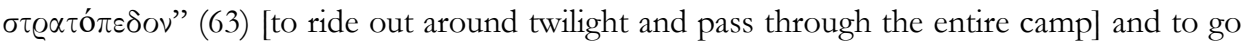
up and survey the whole army at its edge, at a level place projecting a little above the plain. The camp was about 40 stades in dimension, if not more. On August 6, 1256 this happened later than usual, because of the feast of the Transfiguration of Christ. When the author learned that the emperor was on horseback, he got on his mule as quickly as he could and followed

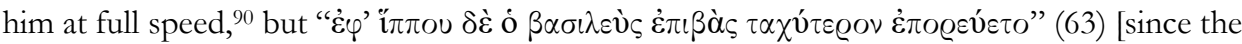
emperor was riding a horse he moved faster]. He saw that Akropolites was not able to keep up with him and asked him to go at a leisurely pace. ${ }^{91}$ Returning from the army inspection on that day, the author argued with the emperor about Ouros's real intentions. Akropolites did not find it easy to be accurate about something which is uncertain. According to Theodore II, it is a gift to be able to give a secure and precise opinion on uncertain matters, and he

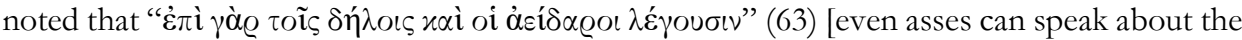
obvious]. Akropolites was offended by these words and thought that he had been classed with the asses. ${ }^{92}$ Theodore II ordered his megas domestikos, Andronikos Mouzalon, to take Akropolites off his mount. ${ }^{93}$ Mouzalon did not have the right conformation for such an activity, as he is described as being thin and weak. He gently asked Akropolites to get off the saddle, and Akropolites dismounted from the mule. ${ }^{94}$ Theodore even ordered two men to beat Akropolites. Hearing the words of Akropolites's prayer, Theodore, as if ashamed, said to one of his attendants to take him, and the attendant put Akropolites on a horse. ${ }^{95}$

On August 15, 1261, Michael Palaiologos entered Constantinople by the Golden Gate, proceeding on foot, while the icon of the Theotokos the Hodegetria preceded him. Gregoras also mentions that, after the recovery of Constantinople, Michael Palaiologos entered the city on foot, walking. He was preceded by the icon of the Virgin Hodegetria. He went as far as

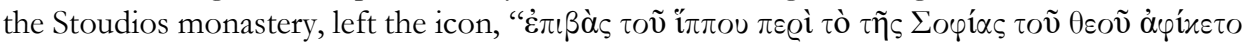
$\tau \varepsilon \dot{\varepsilon} \mu \varepsilon v o \varsigma "$ (88) [mounted his horse and reached the shrine of the Wisdom of God]. ${ }^{96}$

\section{Conclusion}

It is worth noting that most of the horse-related issues raised by the two historiographers of the late Byzantine period are shared: the contribution of the Roman or other cavalry to various battles, the origin of the horses, the suitability of the battlefields for cavalry or areas suitable for horses, care of horses, the mutual support between a horse and its rider or the violence inflicted on horses that results in the riders being hurt. They also mention horses as part of booty, or as an asset, as a means of transport, the symbolic meaning of getting down from a horse, accidents with horses and the relevant protocol. However, no reference to the attitude of the patriarchs towards the use of horses, to the hippodrome, to acrobatics and games using horses, to relevant signs, or the description of a horse in a work of art is made by Akropolites, while these issues are raised by Gregoras. Moreover, there are no references in Akropolites

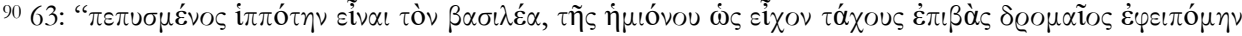

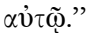

${ }^{91}$ Ibidem, 305.

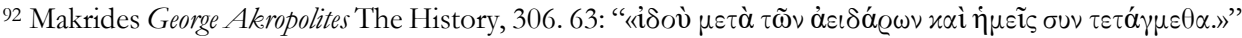

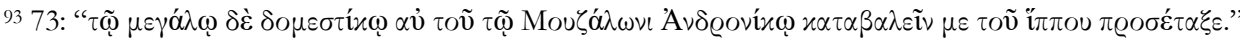

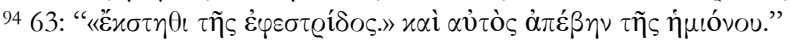

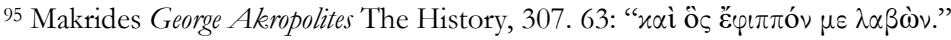

${ }^{96}$ Ibidem, 384.
} 
to figures of speech or to antiquity and biblical and theological quotes, as in the case of Gregoras. On the other hand, only Akropolites refers to the riding of mares, riding without a saddle, the use of camels as means of transport, and the judicial duels of horsemen, while the name of a horse, Goldfoot, is also mentioned in one case. Generally, Akropolites provides much more information about the empire of Nicaea and adds fascinating details and descriptions.

Georgios Akropolites is therefore interested in recording all kinds of information concerning equids, as they prove to be valuable in so many ways: in plunder, in fighting and fleeing, as means of transportation and beasts of burden, as booty or gifts. Cavalry is mentioned in all sorts of battles: among Byzantine states, against their enemies or among allied forces. Certain forces were normally thought to be superior to others, but in fact many factors should be considered. The belief that God's will is above all is strong throughout the texts. The differences in the use of horses are mentioned, as they probably stimulated the writer's interest. It is worth noticing that cavalry was not always provided by the state: instead, people could also contribute using their own horses. However, cavalry also needed to be cared for, so the suitability of the ground for riding is of importance. For example, rivers were not always fordable, and it could be impossible to move or fight on horseback on a downhill ground. Triremes were used to ship the cavalry. Accidents could also happen while marching or fighting. Generally speaking, riding a horse is of course preferable to moving or fighting on foot. In a world where rites were of great importance, Akropolites also provides detailed information about the protocol of turning out and riding equines. Because of the significance of the use of horses, there were related offices and the decoration of the horses was of importance. Cases of getting down from horses are recorded as both signs of shameful submission or intentional respect. Akropolites even bravely records his own experience of having to get down his equine under the pressure of circumstances. Finally, the rare recording of a duel of horsemen as part of a trial is valuable as Akropolites was an eyewitness and a judge. The incorporation of so much information about horses in such a short work testifies to the importance of horses in many sectors of human activity during this Byzantine period.

\section{References}

Dawson, Timothy. Byzantine Cavalryman: c.900-1204. London: Osprey Publishing, 2009.

Dennis, George. "The Byzantines in Battle." In Byzantium at War (9th-12th c.), ed. Kostas Tsiknakis, 165-178. Athens: National Hellenic Research Foundation - Centre for Byzantine Research, 1997.

Georgiadis, Nikolaos. Epitomi istoria ysteris Byzantinis periodou (1204-1461) [Concise history of the late Byzantine period (1204-1461)]. Athens: Bookstars - Free Publishing, 2019.

Haldon, John. Warfare, State and Society in the Byzantine World, 565-1204. London: UCL Press, 1999.

Heisenberg, August. Georgii Acropolitae opera, v. i-ii. Leipzig: Teubner, 1903, reprint Stuttgart, 1978.

Hyland, Ann. The Medieval Warborse from Byzantium to the Crusades. Pennsylvania: Combined Publishing, 1996.

Kanellopoulos, Nikolaos. I organosi kai i taktiki tou vyzantinou stratou stin ysteri periodo (1204-1261) [The organization and military tactics of the late Byzantine army (1204-1261)]. Volos: University of Thessaly, doctoral thesis, 2010.

Kollias, Taxiarchis. Byzantinische Waffen: ein Beitrag zur byzantinischen Waffenkunde von den Anfangen bis zur lateinischen Eroberung. Vienna: Verlag der Osterreichischen Akademie der Wissenschaften 1988. 
Lazaris, Stavros. Le cheval, animal de guerre et de loisir dans l'Antiquité et au Moyen Age: Actes des Journées d'étude internationales organisées par l'UMR 7044 (Études des civilisations de l'Antiquité), Strasbourg, 6-7 novembre 2009. Turnhout: Brepols, 2012.

_. "Le cheval de guerre dans le haut Moyen Âge: élevage, thérapeutique et équipements hippiques." In Vie et mort du cheval: des pratiques médiévales aux traditions camarguaises. Actes $d u$ Xe congrès de la Société d'archéologie médiévale (Arles, 3-5 mai, 2012), ed. Élizabeth Lorans, 2344. Caen: Arles, 2017.

—. "Rôle et place du cheval dans l'Antiquité tardive: Questions d'ordre économique et militaire." In Animal and Environment in Byzantium (7th-12th c.), ed. Ilias Anagnostakis, Taxiarchis Kolias, Eftychia Papadopoulou [National Hellenic Research Foundation Institute for Byzantine Research. International Symposium 21], 245-272. Athens: The National Hellenic Research Foundation, 2011.

Makrides, Ruth (ed.). George Akropolites The History. Oxford: Oxford University Press, 2007. Mango, Cyril. The Oxford History of Byzantium. Oxford: Oxford University Press, 2002.

McGeer, Eric. Sowing the Dragon's Teeth: Byzantine Warfare in the Tenth Century. Washington, D.C.: Dumbarton Oaks Studies 33, 1995.

-. "Infantry versus Cavalry: The Byzantine Response.” Revue des études byzantines 46 (1988): 135-145.

Nicol, Donald. The last centuries of Byzantium 1261-1453. Cambridge: Cambridge University Press, 1993.

Ostrogorsky, George. History of the Byzantine State. New Brunswick: Rutgers University Press, 1969.

Schopen, Ludovicus and Bekker, Immanuel (eds.). Nicephori Gregorae Historiae Byzantinae. Bonn: Corpus Scriptorum Historiae Byzantinae 25-27, 1829-1855.

Treadgold, Warren. Byzantium and Its Army, 284-1081. Stanford University Press 1998. 